\title{
THE EFFECT OF SHAREHOLDING ON DIVIDENDS OBTAINED BY THE REGIONAL GOVERNMENT OF SINJAI REGENCY
}

Jafre-V2I1-05

\begin{abstract}
The purpose of the company is to maximize the wealth of shareholders or owners of the company (wealth of the shareholders). These normative objectives can be realized by maximizing the market value of the company (market value of the firm) .To maximize the value of the company can be achieved through the implementation of financial management functions. This study aims to determine the effect of independent variables namely the ownership of capital and the dependent variable is the dividend of Regional Government of Sinjai Regency. This research is descriptive quantitative. This research uses secondary data in the form of financial statements obtained from PT. Bank Sulselbar branch of Sinjai Regency during the period 2012 to 2016. Data were analyzed by using multiple linear regression analysis. The result of the research showed that independent variable in the form of stock ownership had positive and significant effect to the dependent variable that was obtained by dividend of Government of Sinjai Regency.
\end{abstract}

Keywords: Shareholding, Dividend Earning, financial performance.

\section{PENDAHULUAN}

\section{Latar Belakang}

Tujuan perusahaan yaitu

memaksimalkan

kemakmuran

pemegang saham atau pemilik

perusahaan (wealth of the

shareholders).Tujuan normatif ini

dapat diwujudkan dengan

memaksimalkan nilai pasar perusahaan (market value of the firm). Untuk memaksimalkan nilai perusahaan dapat dicapai melalui pelaksanaan fungsi manajemen keuangan.

Menurut Sartono

manajemen keuangan dapat diartikan sebagai manajemen dana 
baik yang berkaitan dengan

pengalokasian dana dalam berbagai bentuk investasi atau pembelanjaan secara efisien.

Meskipun fungsi seorang manajer keuangan untuk setiap organisasi belum tentu sama, namun pada prinsipnya fungsi utama manajer keuangan meliputi: pengambilan keputusan investasi, pengambilan keputusan pendanaan (pembiayaan) dan kebijakan dividen. Manajer keuangan harus mampu mengambil ketiga keputusan tersebut secara efektif dan efisien. Efektif dalam keputusan investasi akan tercermin dalam pencapaian tingkat keuntungan yang optimal.

Efisien dalam pembiayaan investasi akan tercermin dalam perolehan dana dengan biaya minimum. Sedangan kebijakan deviden yang optimal akan tercermin dalam peningkatan kemakmuran pemilik perusahaan. Ketiga keputusan tersebut secara simultan akan turut menyumbang pencapaian tujuan perusahaan dan peningkatan pertumbuhan ekonomi nasional. Keputusan investasi sangat penting karena akan berpengaruh terhadap keberhasilan pencapaian tujuan perusahaan dan merupakan inti dari seluruh analisis laporan keuangan. Dalam melakukan keputusan pengalokasian ke dalam usulan investasi harus dievaluasi dan dihubungkan dengan risiko dan hasil yang diharapkan. Dalam hal ini perusahaan dihadapkan pada keputusan tentang berapa dana yang harus diinvestasikan pada aktiva lancar dan aktiva tetap serta pos-pos yang terkait dengan aktiva lain-lain perusahaan. Dengan aktiva yang 
tersedia perusahaan harus dapat menghasilkan laba. Keputusan yang menyangkut investasi akan menentukan sumber dan bentuk dana untuk pembiayaannya. Sumber pendanaan dalam perusahaan dapat diperoleh dari internal yaitu laba ditahan, dan eksternal perusahaan berupa hutang atau penerbitan saham baru.

Bank Pembangunan Daerah (BPD) Sulawesi Selatan cabang Sinjai merupakan Bank Pembangunan yang sebagian besar sahamnya dimiliki oleh Pemerintah

\section{LITERATURE REVIEW}

\section{Pengertian Laporan Keuangan}

Menurut Munawir (2004) menyatakan bahwa laporan keuangan pada dasarnya adalah hasil dari proses akuntansi yang dapat digunakan sebagai alat komunikasi
Provinsi Sulawesi Selatan dan Seluruh Pemerintah Kota/Kabupaten yang berada di Provinsi Sulawesi Selatan. Bank Pembangunan Daerah (BPD) Sulawesi Selatan cabang Sinjai merupakan anak perusahaan dari Bank Pembangunan Daerah (BPD) Sulawesi Selatan. Dimana setiap tahunnya membagikan dividen kepada seluruh pemilik saham berdasarkan persentase dari kepemilikan saham dari Pemprov dan pemkot/Kab.di Lingkup provinsi Sulawesi selatan.

antara data keuangan atau aktivitas suatu perusahaan dengan pihak yang berkepentingan dengan data atau aktivitas dari perusahaan tersebut. Menurut Dendawijaya (2009) laporan perhitungan laba rugi atau 
lebih dikenal juga dengan income statement dari suatu bank umum adalah suatu laporan keuangan bank yang menggambarkan pendapatan dan biaya operasional dan non operasional bank untuk suatu periode tertentu.

Menurut Harahap (2002),
"Laporan keuangan adalah
merupakan pokok atau hasil akhir
dari suatu proses akuntansi yang
menjadi bahan informasi bagi para
pemakainya sebagai salah satu bahan
dalam proses pengambilan keputusan
dan juga dapat menggambarkan
indikator kesuksesan suatu
perusahaan mencapai tujuannya.

Menurut Arifin (2002), perangkat laporan keuangan lengkap yang harus diterbitkan oleh bankbank islam terdiri dari :

a. Laporan posisi keuangan (neraca)

b. Laporan laba rugi c. Laporan arus kas

d. Laporan perubahan modal pemilik dan laporan laba ditahan

e. Laporan perubahan investasi terbatas

f. Laporan sumber dan penggunaan dana zakat dan dana sumbangan (apabila bank bertanggung jawab atas pengumpulan dan pembagian zakat).

g. Laporan sumber dana penggunaan dana

h. Catatan-catatan laporan keungan

i. Pernyataan, laporan dan data lain yang membantu dalam menyediakan informasi yang diperlukan oleh para pemakai laporan keuangan sebagaimana ditentukan di dalam Statement of Objective.

\section{Jenis Laporan Keuangan}

Dalam rangka dasar penyusunan dan penyajian laporan keuangan 
standar akuntansi keuangan, laporan keuangan merupakan bagian dari proses laporan keuangan. Laporan keuangan yang lengkap biasanya meliputi neraca, laporan laba rugi, laporan perubahan posisi keuangan yang dapat disajikan dalam berbagai cara misalnya, sebagai laporan arus kas atau laporan arus dana.

Catatan dan laporan lain serta materi penjelasan yang merupakan bagian integral dari laporan keuangan. (Ikatan Akuntan Indonesia, 2007,4).

Menurut Ikatan Akuntan Indonesia $(2007,6)$ dalam PSAK No.

31 Tentang Akuntansi Perbankan, laporan keuangan bank terdiri atas:

a. Neraca

Bank menyajikan aset dan kewajiban dalam neraca berdasarkan karakteristiknya dan disusun

berdasarkan

likuiditasnya.

b. Laporan Laba Rugi

Laporan laba rugi bank menyajikan secara terperinci unsur pendapatan dan beban, serta membedakan antara unsurunsur pendapatan dan beban yang berasal dari kegiatan operasional dan non operasional.

c. Laporan Arus Kas

Laporan arus kas harus melaporkan arus kas selama periode tertentu dan diklasifikasikan menurut aktivitas operasi, investasi, dan pendanaan.

d. Laporan Perubahan Ekuitas Laporan perubahan ekuitas menyajikan peningkatan dan penurunan aset bersih dan kekayaan bank selama periode bersangkutan, berdasarkan 
prinsip pengukuran tertentu yang

dianut dan harus diungkapkan

dalam laporan keuangan.

e. Catatan atas laporan keuangan

Catatan dalam laporan keuangan

harus disusun secara sistematis.

\section{Sifat Dan Keterbatasan Laporan Keuangan Bank}

Standar akuntansi keuangan menyebutkan bahwa laporan keuangan untuk memenuhi kebutuhan-kebutuhan pihak-pihak tertentu saja.Agar laporan keuangan lebih bermanfaat bagi pihak-pihak tertentu yang berkepentingan maka harus dilakukan analisis dan interpretasi terlebih dahulu. Interpretasi laporan keuangan adalah menghubungkan angka-angka yang terdapat dalam laporan keuangan, termasuk hasil analisisnya dengan keputusan usaha yang akan diambil dari hubungan ini dapat dilakukan penilaian terhadap perusahaan yang bersangkutan, sehingga dapat ditarik kesimpulan untuk pengambilan keputusan. Menurut IAI dalam Harahap $(2001,24)$ sifat dan keterbatasan laporan keuangan adalah:

a. Laporan keuangan bersifat historis, yaitu merupakan laporan atau kejadian yang telah lewat. Karenanya, laporan keuangan tidak dapat dianggap sebagai satu-satunya sumber informasi dalam proses pengumpulan informasi ekonomi.

b. Laporan keuangan bersifat umum, laporan keuangan disajikan untuk semua pemakai dan bukan dimaksudkan untuk memenuhi kebutuhan pihak tertentu saja, misalnya untuk pajak, bank dan lain-lainya. 
c. Proses penyusunan laporan keuangan tidak luput dari penggunaan taksiran dan berbagai pertimbangan.

d. Akuntansi hanya melaporkan informasi yang material. Demikian pula penerapan prinsip akuntansi terhadap suatu fakta atau pos tertentu mungkin tidak dilaksanakan jika hal itu dianggap tidak material atau tidak menimbulkan pengaruh yang material terhadap kelayakan laporan keuangan.

e. Laporan keuangan bersifat konservatif dalam menghadapi ketidakpastian, bila terdapat beberapa kemungkinan kesimpulan yang tidak pasti mengenai penilaian suatu pos, maka lazimnya dipilih alternatif yang menghasilkan laba bersih atau nilai aktiva yang paling kecil.

f. Laporan keuangan lebih menekankan pada makna ekonomis suatu peristiwa/transaksi daripada bentuk hukumnya (formalitas).

g. Laporan keuangan disusun dengan menggunakan istilahistilah teknis, dan pemakai laporan diasumsikan memahami bahasa teknis akuntansi dan sifat informasi yang dilaporkan.

h. Adanya berbagai alternatif metode akuntansi yang dapat digunakan menimbulkan variasi dalam pengukuran sumbersumber ekonomi dan kesuksesan suatu perusahaan.

i. Informasi yang bersifat kualitatif dan fakta yang tidak dapat dikuantitatifkan umumnya diabaikan. 


\section{Pendapatan Asli Daerah}

Pendapatan Asli Daerah (PAD)

adalah salah satu sumber penerimaan

daerah yang mendukung kemampuan

keuangan daerah. Pengertian

Pendapatan Asli Daerah menurut

Undang-Undang No.28 Tahun 2009

yaitu sumber keuangan daerah yang

digali dari wilayah daerah yang

bersangkutan yang terdiri dari hasil

pajak daerah, hasil retribusi

daerah,hasil pengelolaan kekayaan

daerah yang dipisahkan dan lain-lain

pendapatan asli daerah yang sah.

Menurut Nurcholis (2007)

pendapatan asli daerah adalah

pendapatan yang diperoleh daerah

dari penerimaan pajak daerah,

retribusi daerah, laba perusahaan

daerah dan lain-lain yang sah.

Pendapatan Daerah adalah

semua hak daerah yang diakui

sebagai penambah nilai kekayaan bersih dalam periode anggaran tertentu (UU No.32 Tahun 2004 tentang pemerintahan daerah), pendapatan daerah berasal dari dana perimbangan pusat dan daerah juga berasal dari daerah itu sendiri yakni pendapatan asli daerah serta lain-lain pendapatan yang sah.

Pendapatan Asli Daerah adalah penerimaan yang diperoleh dari sumber- sumber dalam wilayahnya sendiri yang dipungut berdasarkan peraturan daerah yang sesuai dengan peraturan perundang-undangan yang berlaku yang terdiri atas:

a. Hasil pajak daerah yaitu pungutan yang dilakukan oleh pemerintah daerah kepada semua objek pajak, seperti orang/ badan, benda bergerak/ tidak bergerak.

b. Hasil retribusi daerah, yaitu pungutan yang dilakukan 
sehubungan dengan suatu jasa/ fasilitas yang berlaku oleh pemerintah daerah secara langsung dan nyata.

c. Hasil perusahaan milik daerah dan hasil pengelolaan kekayaan daerah yang dipisahkan antara lain laba dividen, penjualan saham milik daerah.

d. Lain-lain pendapatan asli daerah yang sah antara lain hasil penjualan aset tetap dan jasa giro.

Pendapatan Asli Daerah (PAD) yang tinggi belum merupakan jaminan tingginya pendapatan masyarakat disuatu daerah (regional income). Namun demikian, tingginya PAD dapat menjadi sumber daya yang sangat penting bagi pemerintah daerah didalam pengembangan wilayah termasuk dalam peningkatan pendapatan masyarakatnya (Rustiadi et al. 2010). Perolehan PAD diperlukan manajemen pemanfaatan dana yang mampu digunakan semaksimal mungkin bagi kemakmuran masyarakat yang sebesar-besarnya melalui programprogram dan kegiatan-kegiatan yang diluncurkan pemerintah daerah tersebut (Susanto et al. 2010).

Adapun sumber-sumber pendapatan asli daerah menurut Undang-Undang RI No. 32 Tahun 2004 terdiri dari:

a. Hasil pajak daerah yaitu pungutan daerah menurut peraturan yang ditetapkan oleh daerahuntuk pembiayaan rumah tangganya sebagai badan hokum publik. Pajak daerah sebagai pungutan yang dilakukan pemerintah daerah yang hasilnya digunakan untuk pengeluaran umum yang balas jasanya tidak langsung diberikan 
sedang pelaksanaanya bisa langsung dipaksakan.

b. Hasil retribusi daerah yaitu pungutan yang telah secara sah menjadi pungutan daerah sebagaipembayaran pemakaian atau karena memperoleh jasa pekerjaan, usaha atau milik pemerintah daerah yang bersangkutan. Retribusi daerah mempuyai sifat-sifat yaitu pelaksanaanya besrifat ekonomis, ada imbalan langsung walau harus memenuhi persyaratanpersyaratan formil maupun materiil, tetapi ada alternatif untuk mau tidak membayar, merupakan pungutan yang sifatnya budgetatifnya tidak menonjol, dalam hal-hal tertentu retribusi daerah adalah pengembalian biaya yang telah dilakukan oleh pemerintah daerah untuk memenuhi permintaan anggota masyarakat.

c. Hasil perusahaan milik daerah dan hasil pengelolaan kekayaan daerah yang dipisahkan. Hasil perusahaan milik daerah merupakan pendapatan daerah dari keuntungan bersih perusahaan daerah yang berupa dana pembangunan daerah dan bagian untuk anggaran belanja daerah yang disetor kekas daerah, baik perusahaan derah yang dipisahkan, sesuai dengan motif pendirian dan pengelolaan maka sifat perubahan daerah adalah suatu kesatuan produksi yang bersifat menambah pendapatan daerah, memberi jasa, menyelenggarakan kemanfaatan umum dan memperkembengkan perekonomian daerah. 
d. Lain-lain pendapatan yang sah ialah pendapatan-pendapatan yang tidak termasuk dalam jenis-jenis pajak daerah, restibusi daerah, pendapatan dinas-dinas. Lain-lain usaha daerah yang sah mempunyai sifat pembuka bagi pemerintah daerah untuk melakukan kegiatan yang menghasilkan baik berupa materi dalam kegiatan tersebut bertujuan untuk menunjang, melapangkan, dan memantapkan suatu kebijakan daerah disuatu bidang tertentu. Dana perimbangan diperoleh melalui bagian pendapatan daerah dari penerimaan pajak bumi dan bangunan dari pedesaan, perkotaan, pertambangan sumber daya alam, dan serta bea perolehan hak atas tanah dan bangunan. Dana perimbangan terdiri atas dana bagi hasil, dana alokasi umum, dan dana alokasi khusus. Lain-lain pendapatan daerah yang sah adalah pendapatan derah dari sumber lain misalnya sumbangan pihak ketiga kepada daerah yang dilaksanakan sesuai dengan peraturan perundang- undangan yang berlaku.

Menurut Halim $(2013,101)$ Pendapatan Asli Daerah (PAD) merupakan semua penerimaan daerah yang berasal dari sumber ekonomi asli daerah. Kelompok pendapatan Asli Daerah dipisahkan menjadi 4 jenis pendapatan, yaitu sebagai berikut:

a. Pajak Daerah

b. Retribusi Daerah

c. Hasil Pengelolaan kekayaan milik daerah yang dipisahkan

d. Lain-lain PAD yang sah. 
Undang-Undang No. 5

Tahun 1962 tentang Perusahaan

Daerah memberikan pengertian

tentang yang dimaksud dengan

Perusahaan Daerah adalah semua

perusahaan yang didirikan

berdasarkan undang-undang ini yang

seluruh atau sebagian modalnya

merupakan kekayaan daerah yang

dipisahkan, kecuali jika ditentukan

lain dengan atau berdasarkan

undang-undang. Sedangkan menurut

Undang-Undang RI Nomor 17

Tahun 2003 tentang Keuangan

Negara yang dimaksud dengan

Perusahaan Daerah adalah badan

usaha yang seluruh atau sebagian

modalnya diimiliki oleh Pemerintah

Daerah. Menurut Elita Dewi

$(2002,4)$ mengenai perusahaan

daerah adalah sebagai berikut:

a. Perusahaan Daerah adalah

kesatuan produksi yang bersifat:
Memberi jasa,

Menyelenggarakan pemanfaatan

umum, Memupuk pendapatan

b. Tujuan perusahaan daerah untuk

turut serta melaksanakan

pembangunan daerah khususnya

dan pembangunan kebutuhan

rakyat dengan menggutamakan

industrialisasi dan ketentraman

serta ketenangan kerja menuju

masyarakat yang adil dan

makmur.

c. Perusahaan daerah bergerak

dalam lapangan yang sesuai

dengan urusan rumah tangganya

menurut perundang-undangan

yang mengatur pokok- pokok

pemerintahan daerah.

d. Cabang-cabang produksi yang

penting bagi daerah dan

mengusaihajat hidup orang

banyak didaerah, yang modal

untuk seluruhnya merupakan 
kekayaan daerah yang sesuai pula dengan dasar-dasar dipisahkan pemikiran bahwa segala modal yang

\begin{tabular}{|c|c|}
\hline Selanjutnya & masyarakat \\
\hline Daerah adalah suatu kesatuan & merupakan pengerahan potensi dan \\
\hline produksi yang bersifat memberi jasa, & ada tenaga (funds andforces) dapat \\
\hline menyelenggarakan & diikutsertakan. \\
\hline umum dan memupuk pendapatan. & Sedangkan \\
\hline Perusahaan Daerah dipimpin oleh & Keputusan Menteri Dalam negeri \\
\hline suatu Direksi yang jumlah anggota & dan Otoda Nomor 43 Tahun 2000 \\
\hline dan susunannya ditetapkan dalam & Pedoman \\
\hline peraturan pendiriannya. Direksi & Perusahaan Daerah dengan Pihak \\
\hline berada dibawah pengawasan Kepala & Ketiga Pasal1, menetapkan bahwa: \\
\hline Daerah/ pemegang saham/ saham & "Perusahaan daerah adalah semua \\
\hline prioritet atau badan yang & badan usaha yang modalnya \\
\hline ditunjuknya. & merupakan kekayaan daerah yang \\
\hline Hal ini berarti bahwa masih & pendiriannya \\
\hline
\end{tabular}
swasta ke dalam perusahaan, dan ini 
Penelitian ini dilaksanakan

pada Pemerintah Kabupaten Sinjai

dan Bank Pembangunan Daerah

(BPD) Sulawesi Selatan cabang

Sinjai Sinjai. Data yang digunakan

dalam penelitian adalah data primer dan data sekunder yang bersifat kualitatif maupun kuantitatif. Data primer adalah data yang diperoleh langsung dengan cara observasi atau pengamatan, wawancara, kuisioner, dan opini pakar.

Metode analisis yang digunakan untuk menjawab pertanyaan kajian adalah Analisis regresi dan Analisis kelayakan investasi. Secara detail penjelasan berkaitan dengan metode analisis yang digunakan disajikan. Penelitian ini digunakan analisis regresi. Untuk melakukan pengujian hipotesis penelitian yang telah diajukan sebelumnya digunakan model regresi, dengan persamaan (Sritua Arief :1993) sebagai berikut :

$Y=\alpha+\beta_{1} X_{1}$

Dimana :

$$
\begin{aligned}
& Y=\text { Dividen } \\
& X=\text { Kepemilikan Saham } \\
& \alpha=\text { Kesalahan random }
\end{aligned}
$$

Digunakan analisis regresi terhadap variabel independen yang diduga berpengaruh positif ataupun negatif terhadap Dividen yang diperoleh Pemerintah Kabupaten Sinjai. Model analisis yang digunakan dalam penelitian ini secara teoritis akan menghasilkan nilai parameter model penduga yang sahih bila dipakai asumsi klasik. Karena model analisis regresi linier berganda maka estimasi yang digunakan adalah Metode Kuadrat Terkecil Biasa (Ordinary Leas Squares - OLS) yang mempunyai sifat BLUE (Best, Liner, Unbiased, 
Elimation). Asumsi klasik tesebut menurut Gujarati (1999) alih bahasa Sumarno Zain, terdiri dari: Multikolinieritas,Heteroskedastisitas dan Autokorelasi yang dapat dijelaskan sebagai berikut :

\section{Heteroskedastisitas}

Heteroskedastisitas syarat

klasik dalam Analisis regresi berganda adalah harus tidak terjadi gejala heteroskedastisitas yang berarti varian residual harus sama. Untuk menguji ada atau tidaknya heteroskedastisitas dapat dilihat melalui uji Park .menurut Gujarati (1999) bahwa pengujian park karenanya merupakan prosedur dua tahap. Dalam tahap pertama kita melakukan regresi OLS dengan tidak memandang persoalan heteroskedastisitas, dan melakukan regresi model:
$Y_{i}=\beta_{o}+\beta_{i} X_{i}+\mu$ dari sini akan diperoleh $e_{i}$ kemudian tahap kedua dengan melakukan regresi berikut : $\operatorname{Ln} \mathrm{e}_{\mathrm{i}}^{2}=\alpha+\beta \operatorname{Ln} \mathrm{X}_{\mathrm{i}}+\mathrm{V}_{\mathrm{i}}$

Menurut uji Park jika $\beta$ pada regresi tersebut diatas signifikan secara statistik, maka terhdapat heteroskedastisitas di dalam data.

\section{Pengujian Hipotesis}

Setelah melakukan uji asumsi klasik terhadap data, selanjutnya dilakukan uji hipotesis. Hipotesis penelitian berkaitan dengan ada tidaknya pengaruh variabel independen (X) terhadap variabel dependen (Y), untuk menguji digunakan hipotesis nul $\left(\mathrm{H}_{0}\right)$ yang menyatakan bahwa koefisien regresi tidak signifikan dan hipotesis alternatif $\left(\mathrm{H}_{\mathrm{a}}\right)$ yang menyatakan bahwa koefisien regresi signifikan. Untuk menguji hipotesis 1 dan 2 digunakan alat uji sebagai berikut: 
Pengujian Koefisien Determinasi

$\left(\mathbf{R}^{2}\right)$

Uji koefisien determinasi

$\left(\mathrm{R}^{2}\right)$, digunakan untuk melihat berapa

proporsi/variasi kemampuan

prediktor dari jumlah aktiva tetap,

jumlah hutang jangka panjang,

equity berpengaruh secara bersama-

sama terahadap kinerja keuangan-

profitabilitas PT. Inaport IV

Makassar.Rumus yang digunakan

adalah rumus menurut Gujarati

(1999).

\section{HASIL DAN PEMBAHASAN}

\section{Analisis Regresi}

\section{Uji Hetoroskedastisitas}

Heteroskedastisitas

merupakan syarat klasik didalam

analisis regresi linier yang harus

tidak terjadi yang berarti bahwa

$$
\mathrm{R}^{2}=-\begin{aligned}
& \mathrm{J}_{\mathrm{KR}} \\
& \mathrm{J}_{\mathrm{ky}}
\end{aligned}
$$

Dimana :

$\mathrm{R}^{2} \quad=$ kofisien determinasi

$\mathrm{J}_{\mathrm{KR}}=$ jumlah kuadrat

regresi (explained sum of squares)

$\mathrm{J}_{\mathrm{KY}} \quad=$ jumlah total kuadrat

(total sum of squares)

Semakin besar nilai $\mathrm{R}^{2}$ berarti

semakin besar variasi variabel independen $\mathrm{X}$ terhadap variabel dependen

varian residual harus sama. Dengan menggunakan paket program SPSS versi 20 dapat dideteksi adanya gejala heterokedastisitas melalui grafik scatterplot variabel dependen berikut ini : 


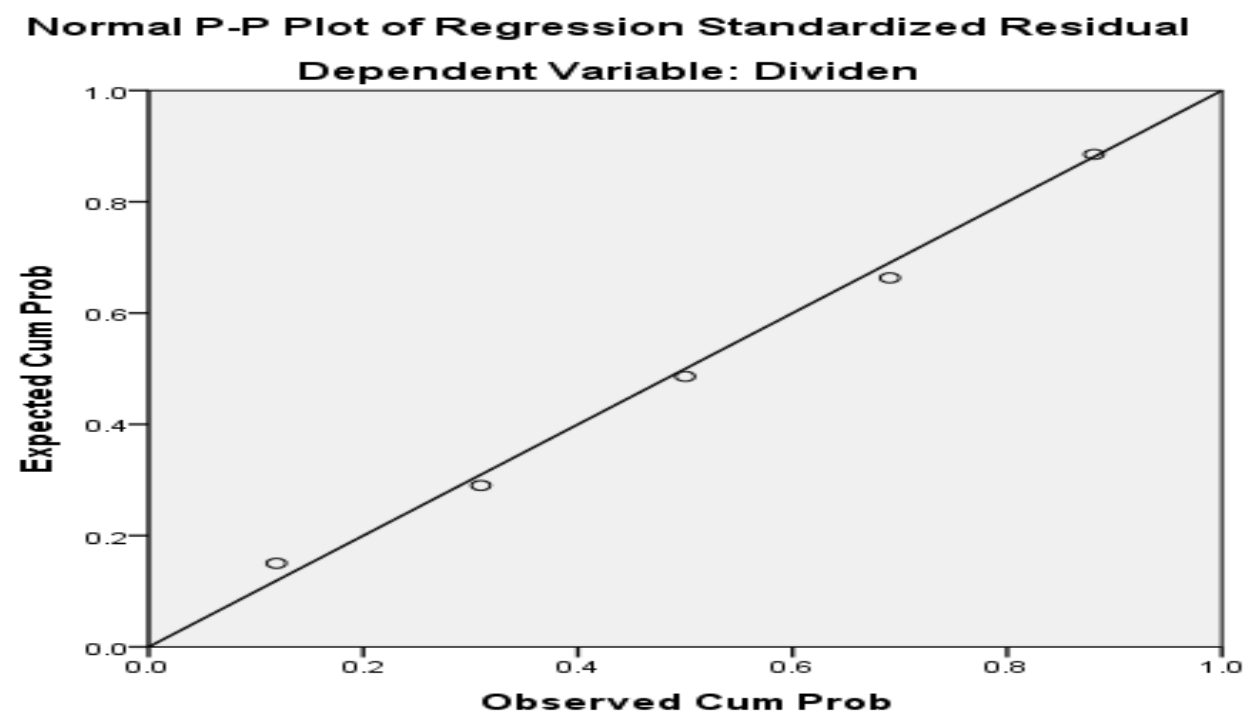

Gambar 1. Grafik Scatterplot Variabel Dependen (Y)

Grafik tersebut diatas

menunjukkan titik-titik menyebar secara acak dan tidak membentuk suatu pola tertentu, disamping itu tersebar di atas maupun di atas angka 0 pada sumbu Y. dengan demikian tidak menunjukkan gejala heteroskestisitas pada model regresi.
Uji Regresi Sederhana

Berdasarkan hasil analisis regresi berganda (multiple regression) dengan menggunakan SPSS versi 20 menunjukkan adanya hubungan dan variasi arah hubungan antara variabel bebas dengan variabel independen. Pengaruh dan arah hubungan tersebut dapat ditunjukkan pada tabel berikut ini : 
Tabel 1. Pengaruh Variabel Bebas (X) terhadap Variabel terikat (Y).

\section{Coefficients $^{\mathbf{a}}$}

\begin{tabular}{|c|c|c|c|c|}
\hline \multirow{2}{*}{\multicolumn{2}{|c|}{ Model }} & \multicolumn{2}{|c|}{ Unstandardized Coefficients } & Standardized \\
\hline & & B & Std. Error & Beta \\
\hline \multirow{2}{*}{1} & (Constant) & -2149546449.844 & 1464769139.249 & \\
\hline & Saham & .544 & .136 & .918 \\
\hline
\end{tabular}

a. Dependent Variable: Dividen

Berdasarkan hasil analisis regersi

dividen adalah sebesar -

pada tabel diatas menunjukkan

2.149.546.450.

bahwa variabel kepemilikan saham

b) Pengaruh Kepemilikan Saham

menunjukkan berpengaruh positif

terhadap Perolehan Dividen

terhadap perolehan dividen. Dari

Nilai koefisien leverage untuk

hasil analisis tersebut maka disusun

kepemilikan saham sebesar 0,544

persamaan regresi sebagai berikut :

dan bertanda positif berarti

$Y=-2.149 .546 .450+0,544 X$

kepemilikan saham mempunyai

Dari hasil persamaan regresi

tersebut maka dapat diinterpretasikan

sebagai berikut :

hubungan yang searah dengan

perolehan dividen. Setiap

kenaikan kepemilikan saham Rp.

a) Konstanta (a)

1,- maka perolehan dividen akan

Ini berarti bahwa jika

meningkat sebesar Rp. 0,544,-.

kepemilikan saham memiliki

nilai 0 (nol) maka peroleh 
Uji $t$

Uji $\mathrm{t}$ digunakan untuk kita menerima hipotesis alternatif, mengetahui apakah variable yang menyatakan bahwa suatu independen secara parsial variabel independen secara parsial berpengaruh nyata atau tidak mempengaruhi variabel dependen. terhadap variabel dependen.Derajat signifikansi yang digunakan adalah 0,05.Apabila nilai signifikan lebih

Tabel 2. Pengaruh Variabel Bebas secara Parsial terhadap Variabel terikat.

\section{Coefficients $^{\mathbf{a}}$}

\begin{tabular}{|c|c|c|c|}
\hline Model & $\begin{array}{l}\text { Standardized } \\
\text { Coefficients }\end{array}$ & $\mathrm{t}$ & Sig. \\
\hline & Beta & & \\
\hline $\begin{array}{ll} & \begin{array}{l}\text { (Constant) } \\
\text { Saham }\end{array}\end{array}$ & .918 & $\begin{array}{r}-1.467 \\
3.998\end{array}$ & $\begin{array}{l}.239 \\
.028\end{array}$ \\
\hline
\end{tabular}

a. Dependent Variable: Dividen

Dari tabel di atas dapat terhadap perolehan dividen.Nilai $\mathrm{t}$ disimpulkan bahwa kepemilikan positif yaitu 3,998menunjukkan saham mempunyai thitung yakni 3.998 bahwa kepemilikan saham dengan $t_{\text {tabel }}=2,353$. Jadi $t_{\text {hitung }}>t_{\text {tabel }}$ mempunyai hubungan yang searah atau $3,998>2,353$ dapat dengan perolehan dividen.

disimpulkan bahwa kepemilikan saham memiliki pengaruh signifikan 


\section{Uji Koefisien determinasi $\left(\mathbf{R}^{2}\right)$}

\begin{tabular}{|c|c|}
\hline determinasi & independen \\
\hline mengetahui & menjelaskan variasi variabel amat \\
\hline seberapa besar hubungan dari & terbatas.Tapi jika hasil mendekati \\
\hline beberapa variabel dalam pengertian & angka 1 berarti variabel-variabel \\
\hline yang lebih jelas. & independen memberikan \\
\hline menjelaskan & semua informasi yang dibutuhkan \\
\hline seberapa besar perubahan atau & untuk memprediksi variasi variabel \\
\hline variasi suatu variabel bisa dijelaskan & dependen. Untuk analisisnya dengan \\
\hline oleh perubahan atau variasi pada & menggunakan output SPSS dapat \\
\hline variabel yang lain (Santosa\&Ashari, & dilihat pada tabel "Model Summary" \\
\hline & j \\
\hline
\end{tabular}

0 dan 1, jika hasil lebih mendekati angka 0 berarti kemampuan variabelvariabel independen dalam

Tabel 3. Pengaruh variabel bebas terhadap variabel terikat

Model Summary ${ }^{b}$

\begin{tabular}{|l|c|r|r|c|}
\hline Model & $\mathrm{R}$ & \multicolumn{1}{|c|}{ R Square } & \multicolumn{1}{c|}{$\begin{array}{c}\text { Adjusted R } \\
\text { Square }\end{array}$} & $\begin{array}{c}\text { Std. Error of the } \\
\text { Estimate }\end{array}$ \\
\hline 1 & $.918^{\mathrm{a}}$ & .842 & .789 & 621538531.20972 \\
\hline
\end{tabular}

a. Predictors: (Constant), Saham

b. Dependent Variable: Dividen

Berdasarkan Tabel 3. dapat terhadap perolehan dividen, disimpulkan bahwa kepemilikan sedangkan $8,2 \%$ dipengaruhi saham berpengaruh sebesar 91,8\% variabel lain yang tidak diteliti. 
Karena nilai $\mathrm{R}$ Square diatas 5\% maka dapat disimpulkan kemampuan variabel independen dalam menjelaskan variasi dependent sangat baik.

Berdasarkan hasil analisis regersi maka didapatkan hasil $\mathrm{Y}=$ 2.149.546.450 + 0,544 X Dari hasil persamaan regresi tersebut maka dapat diinterpretasikan. Nilai Konstanta (a) sebesar -2.149.546.450 Ini berarti bahwa jika kepemilikan saham memiliki nilai 0 (nol) maka peroleh dividen adalah sebesar 2.149.546.450. Nilai koefisien b atau nilai koefisien leverage untuk kepemilikan saham sebesar 0,544 dan bertanda positif berarti kepemilikan saham mempunyai hubungan yang searah dengan perolehan dividen. Setiap kenaikan kepemilikan saham Rp. 1,- maka perolehan dividen akan meningkat sebesar Rp. 0,544,-. Jika :

a. Nilai kepemilikan saham naik sebesar Rp. 2,000,000,000,(dua milyar rupiah) maka dividen naik sebesar Rp. 1,088,000,000,- (satu milyar delapan puluh depan juta rupiah).

b. Nilai kepemilikan saham naik sebesar Rp. 5,000,000,000,(lima milyar rupiah) maka dividen naik sebesar Rp. 2,720,000,000,- (dua milyar tujuh ratus dua puluh juta rupiah).

Pengaruh variabel independen yaitukepemilikan saham berpengaruh terhadap perolehan dividen ditunjukkan oleh koefisien determinasi $\left(\mathrm{R}^{2}\right)$ analisis regresi. Kofisien determinasi $\quad\left(\mathrm{R}^{2}\right)$ menunjukkan proporsi atau 
presentase variasi total dalam variabel dependen perolehan dividen dapat dijelaskan dipengaruhi oleh variabel independen. Hasil analisis regresi berganda (multiple regression) menunjukkan bahwa nilai koefisien determinasi $\left(\mathrm{R}^{2}\right)$ sebesar $\quad 0,918$.hal tersebut menunjukkan bahwa besarnya variasi dari variabel dependen yaitu perolehan dividen. dapat dijelaskan oleh variabel independen adalah sebesar 0.918. Berdasarkan hasil tersebut menunjukkan bahwa variabel independen yang digunakan berupa kepemilikan saham sebesar 91,8\% mampu menjelaskan perubahan perolehan dividen Pemda Sinjai pada PT. Bank Sulselbar Cabang Sinjai, sedangkan sisanya sebesar $8,2 \%$ ini disebabkan oleh faktor lain yang tidak dimasukkan dalam model penelitian.

Hasil perhitungan menunjukkan bahwa kepemilikan saham mempunyai koefisien regresi yang bertanda positif sebesar 0,544 , hal ini menunjukkan bahwa kepemilikan saham memiliki hubungan yang searah dengan perolehan dividen, dan hasil pengujian hipotesis menunjukkan bahwa kepemilikan sahammempunyai thitung yakni 3.998 dengan $t_{\text {tabel }}=2$ 2,353. Jadi $t_{\text {hitung }}>$ $t_{\text {tabel}}$, ini berarti bahwa kepemilikan saham berpengaruh positif dan signifikan terhadap perolehan dividen Pemda Sinjai pada PT. Bank Sulselbar Cabang Sinjai. 


\section{KESIMPULAN DAN SARAN}

\section{Kesimpulan}

Berdasarkan hasil analisis dan

pembahasan yang telah kami

paparkan diatas, maka dapat

disimpulkan bahwa kepemilikan

saham Pemerintah Kabupaten Sinjai

pada Bank Pembangunan Daerah

Cabang SInjai berpengaruh positif

dan signifikan terhadap dividen yang

didapatkan oleh Pemerintah Sinjai.

\section{DAFTAR PUSTAKA}

Agus, Sartono. 1996. Manajemen Keuangan Teori dan Aplikasi. Edisi Ketiga. Penerbit BPFE. Yogyakarta

Arifin, 2002. Pokok-Pokok Akuntansi Lanjutan, Edisi Revisi, Liberty, Yogyakarta.

Arthur J. Keown et., al. 2011. Prinsip dan Penerapan Manajemen Keuangan Edisi 10 Buku 1.Indeks.

Prinsip dan Penerapan Manajemen Keuangan Edisi 10 Buku 1. Indeks.

\section{Saran}

Kami menyarankan kepada Pemerintah Daerah Kabupaten Sinjai danmanajemen Perusahaan Bank Pembangunan Daerah Cabang Sinjai sebagai berikut: Pemerintah Kabupaten Sinjai menambah nilai kepemilikan sahamnya agar dapat meningkatkan secara signifikan nilai dividen yang akan didapatkan.

Dendawijaya, Lukman, 2009, Manajemen Perbankan, Ghalia Indonesia, Jakarta.

Eugene F. Brigham dan Joel F. Hosuton. 2011. Dasar-dasar Manajemen Keuangan Edisi 11 Buku 1. Salemba Empat.

2011.

Dasar-dasar Manajemen Keuangan Edisi 11 Buku 2. Salemba Empat.

Hanif Nurcholis, 2005, Teori dan Praktek Pemerintahan dan Otonomi Daerah, Grasindo, Jakarta. 
Harahap, Sofyan Syafri. 2002.

"Analisa Kritis Atas Laporan Keuangan”, Jakarta : PT Raja Grfindo Persada
Munawir. 2004. Analisa Laporan Keuangan. Yogyakarta: Liberty. 